\title{
Notes on the prospects of Uralic literary studies
}

Remarques sur les perspectives des recherches littéraires ouraliennes

Bemerkungeng zu den Perspektiven der uralischen Literaturwissenschaft DE

\section{Johanna Domokos}

\section{CpenEdition}

\section{Journals}

Electronic version

URL: https://journals.openedition.org/efo/3117

DOI: $10.4000 /$ efo. 3117

ISSN: 2275-1947

\section{Publisher}

INALCO

\section{Printed version}

Date of publication: 1 January 2014

ISBN: 978-2-343-05394-3

ISSN: 0071-2051

\section{Electronic reference}

Johanna Domokos, "Notes on the prospects of Uralic literary studies", Études finno-ougriennes [Online], 46 | 2014, Online since 08 October 2015, connection on 08 July 2021. URL: http:// journals.openedition.org/efo/3117 ; DOI: https://doi.org/10.4000/efo.3117

This text was automatically generated on 8 July 2021.

\section{(c) (1) (8)}

Études finno-ougriennes est mis à disposition selon les termes de la Licence Creative Commons Attribution - Pas d'Utilisation Commerciale 4.0 International. 


\title{
Notes on the prospects of Uralic literary studies
}

\author{
Remarques sur les perspectives des recherches littéraires ouraliennes \\ Bemerkungeng zu den Perspektiven der uralischen Literaturwissenschaft DE
}

Johanna Domokos

1 In the classical phase of Uralic/Finno-Ugric Studies, which lasted from the nineteenth century until the mid-twentieth century, the discipline's main object of inquiry was comparative and historical linguistics. This entailed a systematic analysis of the interrelations of languages considered to be part of the Uralic language family. Although oral literature was considered the most important source of language data, the medium of written literature received very little attention. In the second half of the twentieth century, however, Uralic Studies expanded its disciplinary interests to catch up with other (post)modern humanistic disciplines.

2 Why is it important to question the cultural diversity that dominates the field of comparative literature? And why has it become important for Uralic Studies to move out of the linguistic paradigm? How can we encourage the spread of Uralic literatures into the stream of world literature? These are the three main questions that I direct towards Uralic Literary Studies. Since the only international forum for Uralic literature(s) has been created and exercised by Uralists themselves, this paper addresses the major issues of Uralic (Literary) Studies with an eye toward the future of the discipline.

\section{How multidisciplinary can/should Uralic Studies be?}

With the pioneering works of nineteenth-century researchers such as A. Reguly and M.A.Castrén, the field of Uralic Studies cultivated interest not only in historical linguistics but in other cultural phenomena as well. Folklore and ethnology also became quite strong pillars of the field in its early years. Later, in the second half of the twentieth century, Uralic Studies spurred further excellent research in anthropology, 
archeology, history, sociology, semiotics and literary studies (see the works of Thomas Sebeok, Péter Domokos, Lauri Honko, Anna-Leena Siikala, Vilmos Voight, Raija Bartens, János Pusztay, Johanna Laakso, etc.). Some of the (sub)fields of Uralic Studies have grown into internationally relevant schools (e.g. folklore, anthropology and semiotics), while others still lack the necessary encouragement and/or acknowledgement inside and outside of the discipline (e.g. cultural ecology, musicology, translation and literary studies, sociology, media studies).

\section{Uralic Studies and other cultural fields}

Uralic Studies engages with a unique and vast range of cultural material, including arti-, socio-, mentifacts and cultural practices of about 20-30 ethnic and national cultures. Thus it is obvious that the field demonstrates unquestionable originality and relevance. Aside from the national and ethnic analytical interests of Departments of Uralic Studies and the Uralic people themselves, there is no other place where Uralic cultures receive scholarly attention.

5 Due to its foundations in historical linguistics, and its continuously growing interests in all aspects of culture, the discipline of Uralic Studies shares methodological and theoretical affinities not only with Indo-European Studies but also with Romance and Germanic Studies. While there is a need for Uralic Studies to reevaluate its own inner multi- and interdisciplinary methodological and theoretical dialogue, it is also necessary for the discipline to open itself beyond immediate Uralic concerns. Owing to the influence of interethnic networking with non-Uralic ethnic groups, the field of Uralic Studies needs to restructure itself into something comparable to Inter-American or TransArea Studies.

\section{Impulses of Cultural Studies and Multiculturalism}

6 I consider one of the main tasks of a cultural field like Uralic Studies to be the examination of all kinds of Uralic cultural phenomena. This includes the diverse arti-, menti-, and sociofacts as well as cultural practices of particular Uralic groups throughout their historical evolution. In these processes, intracultural and Uralic networking is just as important as intercultural (non-Uralic) networking. In recent decades, cultural studies have developed a set of new approaches to the study of culture and society, which cannot be overlooked by other humanistic disciplines. Moreover it has contributed to the so-called "cultural turns" of the sciences as well. Cultural Studies has made us aware of the relevance of cultural processes while critically examining the unbalanced power practices inherent in collective signifying processes. Because of its focus on the representations of sociostructural categories like race, gender, and class in all kinds of media, cultural studies complements the multiculturalist program developed in the field of socio-politics. Although all societies are composed of diverse units, which have developed throughout history, the nationalist discourse of past centuries imagined large and homogenous social units, masking diversity with hegemonic, exclusionary ideology. Therefore it is high time we activated the multiculturalist paradigm in the field of Uralic Studies. This is more important now than ever, since the (re)vitalization of most of Uralic cultures is one of the main tasks facing Uralic Studies today. 


\section{Comparative literature and Uralic Studies}

One of the central tasks of comparative literary studies is to define and promote world literature as well as developing the necessary critical tools for its comparative analysis. This requires a form of detached engagement with all literature, and all kinds of literary worlds, not only with the dozen or so national literatures and canons promoted by today's book market. If we are to understand world literature as a mode of production, circulation, and reading of literary works, then drawing attention to the corpus of individual Uralic literatures can be an appropriate way to increase the variability of works inside the field. This process would support Damrosch's observation that

One of the most exciting features of contemporary literary studies is the fact that all periods as well as all places are up for fresh examination and open to new configurations (2003, p. 27).

It is well known that world literature can only exist as multicultural practice; however the practical dominance of a dozen literatures cannot reflect the real diversity of this field. As Heilbron and Sapiro remark, more than half of the books circulated in the global market are in the English language. French, German and Russian books comprise around ten percent each, while the literature written in Italian, Spanish, Polish, Danish, Swedish and Czech together take up nearly one percent (2011). The remaining is for the rest: the literatures outside of the Euro-American World. Heilbron and Sapiro draw our attention to a contradictory development in our age of globalization by stating that the overall share of the above mentioned $1 \%$ decreases while the total number of translated books shrinks from year to year (e.g. from less than $20 \%$ in the 1980 s to $14 \%$ in the 1990s, 2007 p.97).

\section{On the ecology of the Uralic Literary Field (ULF)}

The two approaches mentioned above, Comparative Studies and Uralic (Cultural) Studies, form the background upon which Uralic Literary Studies can build itself and make a positive, unique contribution.

Uralic literature (singular) encompasses literature produced in any of the Uralic languages as well as in the official languages of the states where authors with a special Uralic ethnic identity live. The field intertwines itself with networking dispositives that ensure a special degree of integration, connection and cultural interlocking among the particular literary subfields. The term "Uralic literatures" (plural) has also been strongly constructed along the concept of Uralic languages, enlivened and performed mostly by people who are in minoritarian positions in Scandinavia and Russia (see the works of Péter Domokos). Meanwhile the more established Uralic literatures, such as Finnish and Hungarian, come from groups with a longer national history, and their literary agents are less inclined to incorporate a minoritarian paradigm. Nevertheless, it is important to realize that both expressions are the product of comparative literary theories and interests, not historical relationships.

11 Human networking (e.g. meetings of Uralic people) and the distribution of literary translations are the two main sources that favor the networking dispositives of ULF. Literature as an exemplificatory medium of art and culture enjoys high prestige among 
all Uralic people. Even though they rely on fictional worlds, Uralic literatures offer valuable insights into relevant issues of everyday life, and they fulfill all the criteria cultural ecology as well as theory of normalism (cf. the works of Jürgen Link) find relevant. They work as critical metadiscourse, as imaginative contra-discourse as well as a reintegrative innerdiscourse. Therefore beyond their relevance for the humanities, ULF can be an object of study for the life sciences as well. These literary fields contain a vast amount of information about the performativity of culture in highly multicultural and transcultural settings, as well as local, regional, and global aspects of power practices and ecological and ecocultural issues (just to mention some of the many possibilities). Since most of the Uralic languages are endangered or highly endangered, the ecology of their literatures and cultures are also highly endangered. The creative usage of the language leading to literary works contributes enormously for keeping a linguistic community in their traditional communication. Literature is the creative, open space of the language, where revision, implementation as well as language renewal can happen.

\section{Closing remark}

This paper has offered a very cursory insight into the ways Uralic Studies can contribute to other humanistic fields, as well as orienting itself in a multicultural world. On one hand, I have outlined some of the internal goals of Uralic Literary Studies in redefining itself along the lines of the important academic fields of the twenty-first century. On the other hand, I have offered a critical look at the field of Comparative Literature, which is in part responsible for the tendency toward homogeneity in world literature.

13 Linguistic, literary and cultural practices are closely intertwined in literary texts. It should come as no surprise that "culture as text" has recently garnered so much support, given the recent scholarly interest in literature as cultural practice, as well as the return of literature to philology. In his famous essay, Return to Philology, E. Said underlined that

...literature provides the most heightened example we have of words in action and therefore is the most complex and rewarding - for all sorts of reasons - of verbal practices (Said 2004, p. 60).

With this acknowledgement in mind, the field of Uralic literature needs to be placed at the core of Uralic Studies, as well as that of Comparative Literature. With an expansive and multilayered focus on sign/text/language performance and sign/text/language history, Uralic Studies can meet the challenges of twenty-first century scholarship.

BIBLIOGRAPHY

DAMrosch, David, 2003, What is world literature? Princeton, Oxford: Princeton University Press. 
DELEUZE Gilles, GUATTARI Félix, 1975, Kafka : pour une littérature mineure, Paris : Les Éditions de Minuit.

DомоKоS Johanna, 2011, "Differentiation of cultural interference of the (Uralic) literary field", in J. Laakso, J. Domokos (ed.), Multilingualism and multiculturalism in the Uralic literatures, FUSA Vol. 8 , p. 12-25.

DOMOKOS Johanna, 2012, “Na cestě k pestrosti” (= Towards literary diversity), Plav Vol. 21. p. 2-9. ромокоs Péter, 1985, A kisebb uráli népek irodalmának kialakulása, Budapest: Akadémia Kiadó. DомоKоs Péter, 2003, “A kisebb uráli (finnugor) irodalmakról”, Magyar Napló XV/4, p. 20-25. ромокоs Péter, 2008, “A finnugor népek irodalmának fejlődési problémái”, in Ünnepi írások Havas Ferenc tiszteletére. Urálisztikai Tanulmányok 18. Budapest, p. 163-167.

ETTE Ottmar, 2010, "Literaturwissenschaft als Lebenswissenschaft. Eine Programmschrift im Jahr der Geisteswissenschaften", in Olfgang Asholt, Ottmar Ette (ed.), Literaturwissenschaft als Lebenswissenschaft, Tübingen: Narr Verlag, p. 11-38.

HEILBRON Johan, SAPIRO Gisèle, 2007, "Outline of a sociology of translation”, in Michaela Wolf (ed.), Constructing a Sociology of Translation, Amsterdam, Philadelphia: Benjamins Press, p. 93-107.

LAAKSO Johanna, 2006, “Subjektina ja objektina. Fennougristiikka ja suomalaisugrilaisuus, naistutkimus ja naiseus”, in Taru Nordlund, Tiina Onikki-Rantajääskö \& Toni Suutari (ed.), Kohtauspaikkana kieli. Näkökulmia persoonaan, muutoksiin ja valintoihin, Helsinki: Finnish Literature Society. p. 448-461.

LAAKSO Johanna, 2009. "Zwischen Sprache und Literatur. Gedanken zu Fragen der finnischugrischen Literaturwissenschaft”, in Ágoston Zénó Bernád, Márta Csire \& Andrea Seidler (szerk.), On the Road - Zwischen Kulturen unterwegs, Finno-Ugrian Studies in Austria 7, Wien: LIT-Verlag, p. 330-339.

LAAKSO Johanna (ed.), 2010, Multilingualism and multiculturalism in Finno-Ugric literatures, FinnoUgrian Studies in Austria 8, Wien: LIT-Verlag.

SAID Edward, 2004, Humanism and democratic criticism, New York: Columbia University Press.

\section{ABSTRACTS}

Why is it important to question the cultural diversity that dominates the field of comparative literature? And why has it become important for Uralic Studies to move out of the linguistic paradigm? How can we encourage the spread of Uralic literatures into the stream of world literature? These are the three main questions the present paper directs towards Uralic Literary Studies. Since the only international forum for Uralic literature(s) has been created and exercised by Uralists themselves, this paper addresses the major issues of Uralic (Literary) Studies with an eye toward the future of the discipline.

Pourquoi est-il important de s'interroger sur la diversité culturelle qui domine le domaine de la littérature comparée ? Et pourquoi est-il devenu important pour les études ouraliennes de sortir du paradigme linguistique? Comment pouvons-nous encourager la diffusion des littératures ouraliennes dans la littérature mondiale ? Ce sont là les trois questions principales que cet article pose sur les études littéraires ouraliennes. Depuis que l'unique forum international abordant la littérature ouralienne - les littératures ouraliennes - a été créé et animé par les ouralistes euxmêmes, cet article s'interroge sur l'avenir de la discipline. 
Warum ist es wichtig, die kulturelle Vielfalt, die das Feld der vergleichenden Literaturwissenschaft dominiert, infrage zu stellen? Und warum lohnt es sich für die Uralistik aus dem linguistischen Paradigma sich herauszubewegen? Wie können wir die Ausbreitung der uralischen Literaturen in den Strom der Weltliteratur fördern? Dies sind die drei wichtigsten Fragen, welche die vorliegende Arbeit zur uralischen Literaturwissenschaft leitet. Da die wichtigsten internationalen Foren für uralische Literatur(en) von Uralisten erstellt wurden und und immer noch durch Uralisten am meistens praktiziert werden, befasst sich diese Studie mit den aktuellsten Fragen der uralischen Literatureissenschaft mit einem Auge auf die Zukunft

\section{INDEX}

Chronological index: XXIe siècle (début), XXIe siècle

Keywords: Cultural Studies, Multiculturalism, Uralic Literary Studies, Comparative Literature, Cultural Ecology, English, Czech, Danish, Finnish, Literary Studies, French, German, Hungarian, Italian, Polish, Russian, Spanish, Swedish, Russia, beginning of the 21st century

Mots-clés: cultural studies, multiculturalisme, littérature ouralienne, écologie culturelle

disciplines estonien, finnois, hongrois, khanty, russe

Geographical index: Fédération de Russie, Scandinavie

Subjects: études littéraires, littérature comparée 